\title{
THE FOOD OF THE MONGOOSE (HERPESTES JAVANICUS AUROPUNCTATUS HODGSON) IN ST. CROIX AND PUERTO RICO ${ }^{1}$
}

\section{George N. Wolcott ${ }^{2}$ \\ INTRODUCTION}

The mongoose has been receiving so much unfavorable publicity recently that any apparently beneficial aspects of its presence in Puerto Rico should be made known. One may wonder how it manages to capture and swallow a centipede, and admire its courage in attacking a tarantula, or speculate on how it finds so many of these animals to devour, but recent examination of the stomach contents of 98 freshly killed individuals indicates that centipedes and tarantulas form an important part of its food.

G. A. Seaman, Wildlife Supervisor of the Virgin Islands, shot 42 of Herpestes javanicus auropunctatus Hodgson in St. Croix during the past year and submitted the stomach contents for critical examination as to the insect remains present. David Pimentel of the U. S. Public Health Service has aided in the examination of 56 specimens caught mostly. at Roosevelt Roads, Puerto Rico, during the summer and autumn of 1952. As a result of these observations, it appears that the mongoose eats very much the same items of food in St. Croix as in Puerto Rico: Mostly lizards, rarely a mouse or rat, a bullfrog or culebrita (blind-snake), but centipedes and tarantulas almost as often as lizards. Most of the insects it eats are Orthoptera: Wild cockroaches (not the ones found in houses), tree crickets, cave crickets, and ground crickets, besides both brown and green grasshoppers. Because it eats so many lizards, it may be presumed that some, or indeed most of the other insects found in the stomach of the mongoose when the remains of a lizard are also present, were originally eaten by the lizard. Houseflies and ants may have been eaten incidentally because they were present on the fish bait used to attract the mongoose, and should not be considered part of its normal food.

The problem of determining what the mongoose eats in nature is complicated by the fact that it quite thoroughly chews its food before swallowing, and that digestion of the comminuted food particles is rapid after entering the stomach. This is in very decided contrast to the feeding habits of lizards

\footnotetext{
Extemporaneously presented at the annual meeting of the American Society of Agricultural Sciences held at Río Piedras, Puerto Rico, November 13, 1952, entitled "The Mongoose Eats Centipedes and Tarantulas."

2 Entomologist and Head of the Department, Agricultural Experiment Station, University of Puerto Rico, Río Piedras, P. R.
} 
$(1)^{3}$, toads (2 and 3), and frogs (4), which swallow their food whole. Entire insects may be recovered intact and in such perfect condition that several species of Puerto Rican thrips (5) were described from material first collected in the stomachs of lizards.

Previous attempts to determine what the mongoose eats in Puerto Rico were failures, all the stomachs sent by Thos. H. Jones to the Bureau of Biological Survey in 1912 having proved to be empty. If the mongoose is caught in a trap visited only once or twice a day, digestion usually will have been so complete by the time the animal is dissected that nothing remains in the stomach for examination. It is quite essential, therefore, that the animals attracted to a bait in the field be shot and dissected immediately. My associate, Luis F. Martorell, tells me that he and other boys in Yabucoa used to shoot those attracted by the peeping of a baby chick separated from the mother hen, but this was merely sport, and no observations on stomach gontents were made by him at this early stage of his scientific career. If the mongoose has already begun to eat of the bait at the time that it is killed, and a quantitative estimate is desired, such remains of fish vertebrae and flesh should be subtracted from what is found in the stomach, even though already thoroughly mixed with the comminuted remains of what had previously been eaten.

\section{ITEMS IDENTIFIED FROM MONGOOSE ALIMENTARY TRACTS}

Qualitatively, the identification of the various items of the stomach contents is by no means simple and specific determinations must often be largely a matter of conjecture based on the known fauna of the area inhabited by the mongoose. Yet in one instance, half the tarsal claw of a maybeetle ${ }^{4}$ authenticated the species, although all other remains, including even the heavily chitinized elytra and prothorax, had been eliminated. Thus the following detailed list of items found is given with the caution that while presumably exact for the common animals recorded, some puzzling fragments found but once or twice may not have been correctly identified.

Items identified from the alimentary tracts of the Mongoose, Herpestes javanicus auropunctatus Hodgson, 42 from St. Croix, 56 from Puerto Rico

\section{Vertebrates:}

3 masses of hair of mongoose (identified by

3 masses of hair of rat $\quad$ Mr. Seaman or

2 masses of hair of mouse Dr. Pimentel

1 introduced bullfrog, Rana catesbeiana Shaw

${ }^{3}$ Numbers in parentheses refer to Literature Cited, p. 247.

"Although Dr. Wolcott prefers the form "May beetle," the January 1953 Edition of the U. S. Government Printing Office Style Manual, which is followed in editing this Journal, prescribes the form "maybeetle," presumably on the advice of a consensus of State and Federal entomologists. Ed. 
2 treetoads or "coquís", Eleutherodactylus auriculatus Cope

2 blind-snakes or "culebritas", Typhlops lumbricalis Linnaeus

46 lizards, mostly Anolis cristatelus Duméril and Bibron some Anolis pulchellus Duméril and Bibron, Ameiva exsul Cope possibly other species also

\section{Invertebrates:}

1 fiddler crab from beach at St. Croix, reported by Mr. Seaman

4 land crabs or "jueyes", Cardisome guanhumi Latreille

1 beach flea, Orchestia platensis Kroger, from beach at St. Croix

38 centipedes, Scolopendra subspinipes Leach

3 small unidentified spiders

2 large spiders or tarantulas from St. Croix, (?)('yrtopholis bartholomei

14 tarantulas, Cyrtopholis portoricae Chamberlin

1 daddy longlegs

Insects :

4 earwigs, Labia curvicauda Motschler

37 (or more) cockroaches, 9 or more Pycnoscelus surinamensis Linnaeus

1 Epilampra wheeleri Rehn, 1 the green Panchlora cubensis Saussure,

1 Eurycotis improcera Rehn, from St. Croix

other unidentified to species

24 large yellow-brown short-horned grasshoppers, Schistocerca americana Thunberg

18 large green (or red) katydids or long-horned grasshoppers, Neoconocephalus triops Linnaeus

46 crickets:

15 Orocharis vaginalis Saussure

9 Ablona (or Gryllacris) guadeloupensis Karny, from St. Croix

13 cave crickets, Amphiacusta caraibea Saussure

9 ground crickets, Acheta assimilis Fabricius

1 damselfly, Lestes forficula Rambur

1 cicada, Proarna hilaris Germar

2 chinchbugs, Blissus leucopterus Say

2 stinkbugs, Euschistus bifibulus PB

1 Carabid beetle, Calosoma alternans Fabricius

1 small Bostrychid beetle

2 fragments of elytra of small unidentified beetles

1 elytron of Ligyrus cuniculus Fabricius, from St. Croix

1 head of white grub, (?)Phyllophaga microphylla Moser, from St. Croix

2 female maybeetles, Phyllophaga portoricensis Smyth

$1 / 2$ tarsal claw of maybeetle, Phyllophaga portoricensis Smyth

1 bean Chrysomelid beetle, Cerotoma ruficornis Olivier (entire, probably caught originally by lizard)

4 leaf weevils, Diaprepes abbreviatus Linnaeus

1 Stratyomyid fly, Neorondania chalybea Wiedemann

1 blowfly, Callitroga hominivorax Coquerel, probably from fish bait

4 adults and 2 maggots of the housefly, Musca domestica Linnaeus

1 Anthomyid fly, Fannia pusio Wiedemann

1 Calobatid fly, Taeniaptera lasciva Fabricius

many very small flies, probably from fish bait 
1 adult and 1 caterpillar of Hesperiid butterfly

1 small parasitic wasp, wing only

Ants

12 "berraco", Odontomachus haematoda Linnaeus (heads or entire ants)

1 Monomorium sp.

7 "hormiga brava", Solenopsis geminata Fabricius

10 Pheidole megacephala Fabricius

2 "albaricoque", Tapinoma melanocephala Fabricius

2 "hormiga loca", Paratrechina longicornis Latreille

\section{EVALUATION}

In attempting to appraise the impact of the mongoose on its environment as it affects the interests of man, one finds that too little is known regarding the food habits of some of the animals eaten. Those of the lizards of Puorto Rico are, however, well known. As predators on insects, their value is so obvious generally, and is so apparent to even casual observation, that one must forgive their interest in brightly colored and conspicuous ladybeetles. Many ladybeetles have an offensive odor (or at least an odor offensive to man) and it has been claimed that their bright warning colors prevent birds from eating them a second time.

Unfortunately for this theory, lizards swallow any moving object that looks like food, even the prickly, hairy woolly-bear caterpillars of Ecpantheria icasia Cramer, and so quickly that they never taste what they swallow, but merely react with apparent pleasure and satisfaction to the struggles of their living food as it goes down. Instead of being repelled by bright colors, they may swallow bright-colored berries and even eat immobile scale insects that are the shape and size of ladybeetles. Before the introduced Surinam giant toad had minimized the maybeetle population of Puerto Rico, even these exclusively nocturnal insects were eaten by the diurnal crested lizard. The ground lizard or "iguana", Ameiva exsul Cope, which appears above ground only during the middle of the day, burrows rapidly through the soil and eats the eggs of maybeetles and the white grubs that hatch from them. Thus, although lizards may destroy some beneficial insects, the bulk of what they eat are either neutral insects, or those definitely deleterious to man's welfare.

The Hispaniolan tarantula, Phormictopus cancerides Latreille, has been kept alive for long periods on captivity when fed principally on cockroaches and lizards. Jorge J. Serrallés kept one female for 12 years, for which ho always brought back a mate when returning from Santo Domingo. The fate of the male was always the same, however; he was murdered within a few days and his skin sucked dry and rolled into a pellet by the female. Luis F. Martorell kept a female for 8 years which molted regularly during March or April, 
and was fed principally the lizards which managed to penetrate the tightly screened insectary.

Of the Puerto Rican tarantula, Cyrtopholis portoricae Chamberlin, Alexander Petrunkevitch (6) says that "at the mouth of the burrow one may commonly see remains of large millipedes, constituting the chief food of these spiders." This observation, entirely correct at the time it was made, no longer applies to present conditions in Puerto Rico, for the imported giant toad has nearly eliminated millipedes locally. Years ago, more than one elytron and prothorax of maybeetles was noted at the entrance of holes in the ground presumably made either by the tarantula or the centipede, but maybeetles are no longer sufficiently abundant in Puerto Rico to serve as a dependable source of food every year and at all times of year for either toad, tarantula, or centipede.

Indeed, one can but wonder what tarantulas and centipedes do find to eat in any abundance since the advent of the toad, for their holes seem to be quite as numerous now as at any time in the past. If one considers these animals as merely ugly, nocturnal, and potentially dangerous creatures liable to attack man, the role of the mongoose in destroying them can be regarded as entirely beneficial. From another more basic point of view extensive destruction of centipedes and tarantulas may be to some extent, or even largely, against the best interests of man. Of this we cannot judge, however, without determining the main items in their food at the present time.

No records exist of outbreaks of grasshoppers in Puerto Rico, at all comparable to those in other countries, before the introduction of the mongoose here. Indeed it is very doubtful whether the comparative scarcity of grasshoppers and katydids in Puerto Rico is due, except to a very minute extent, to their being eaten by the mongoose. Never having been economic pests here, they can hardly be considered as even potentially dangerous to the economic interests of man. Almost similarly neutral, or of negligible importance, are most of the other Orthoptera eaten by the mongoose. One of the tree crickets of St. Croix, Ablona guadeloupensis (Karny), as A. B. Gurney states this Lesser Antillean species of Gryllacris must now be called, is indeed so inconspicuous and hard to catch as never to have been collected there before Seaman found one wrapped in a curled-up grapefruit leaf. He thought it probably responsible for damage to young fruit trees, attacking tender shoots and leaves. Other tree crickets, the cave crickets, and the common ground crickets may also at times be minor pests, but in no case did the mongoose eat such a major pest in Puerto Rico as the changa.

The cockroaches consumed by the mongoose were not the species common in houses, but wild species hardly affecting the interests of man in any way. The very decided preference of the mongoose for Orthoptera, to the exclusion of practically all other insects (if one eliminates those ants and flies 
which were eating the fish bait, and those which had been previously caught and swallowed by the lizards the mongoose ate), seems most remarkable, and is as definite as that of any systematic entomologist interested in only his own group of insects. But it is not unique for the West Indies, as C. E. Pemberton (7) in Hawaii lists "crickets, grasshoppers, the locustid Conocephalus saltator, the grasshopper, Oxya chinensis" first, subsequently mentioning spiders, caterpillars, beetles, bees and wasps, with no indication of comparative abundance.

The names of small ants are as conspicuous in the list of food items as those of the largest grasshopper, yet by actual bulk and mass, thousands of ants are required to equal one grasshopper. All the Orthoptera: Cockroaches, grasshoppers, katydids and crickets, are comparatively large insects, and in St. Croix they constituted such a large fraction of the insect food that the presence of an occasional ant or small fly in reality contributed little or nothing to the nourishment of the mongoose.

Numerous other large insects occur in Puerto Rico, often in such abundance as to consitute definite pests, and all presumably available to the mongoose to catch and eat if it so desires. Yet the preponderance of Orthoptera in the food preferences of the mongoose in Puerto Rico is almost as marked as in St. Croix. To be sure, a few maybeetles, Phyllophaga portoricensis Smyth, and a few leaf weevils, Diaprepes abbreviatus Linnaeus, were found in the stomachs examined, and these beetles may actually have been caught by the mongoose, and not first eaten by lizards. If so, they are the only items in its food which can with assurance be considered as pests, as contrasted with the much greater number of beneficial lizards, and the centipedes, tarantulas, and orthopterous insects with a status neutral or undetermined. Thus, in any realistic appraisal of the food habits of the mongoose in St. Croix and Puerto Rico, it must be considered definitely deterimental, or certainly of negligible value in the control of any major insect pests.

\section{SUMMARY}

Riki-tiki-tavi, an Indian mongoose, was a hero in Rudyard Kipling's "Jungle Book" because he killed cobras and other poisonous snakes. Brought to West Indian islands such as St. Croix, where there are no snakes, or very few as in Puerto Rico, the mongoose, attacking the nearest local counterpart to snakes, primarily feeds on lizards. Lizards are insectivorous and considered largely beneficial. Indeed, most of the insect pests found in the stomach contents of the mongoose presumably were originally caught by lizards. The insects eaten by the mongoose are practically all Orthoptera: Grasshoppers, katydids, crickets, and cockroaches. Of other Arthropods, it eats mostly large spiders or tarantulas, and centipedes. 


\section{RESUMEN}

Riki-tiki-tavi, una mangosta de la India, fué el héroe en el "Libro de la Selva" de Rudyard Kipling, por su habilidad para matar cobras y otras serpientes venenosas. Traída a las Antillas donde no hay serpientes, como sucede en Santa Cruz, o muy pocas como en Puerto Rico, la mangosta se dedicó a atacar lo más que se le parecía a una culebra, principalmente lagartijas.

Las lagartijas son insectívoras y por lo tanto se consideran beneficiosas a la agricultura. De hecho, la mayor parte de los insectos dañinos que se encontró en los estómagos de las mangostas observadas, con toda probabilidad fueron originalmente atrapados por lagartijas.

Los insectos que come la mangosta en su mayoría son ortópteros, tales como saltamontes, grillos y cucarachas. También come tarántulas y ciempiés.e

\section{LITERATURE CITED}

1. Wolcott, George N., The food of Porto Rican lizards, J. Dept. Agr. P. R. 7 (4) 5-37 (ref. 8) 1924.

2. Dexter, Raquel, R., The food habits of the introduced toad, Bufo marinus, in the sugar-cane sections of Porto Rico, Bull. 74, Fourth Congress, International Society of Sugar-Cane Technologists, pp. 6, (ref. 6), March 1 to 16, 1932.

3. Wolcott, George N., What the giant surinam toad, Bufo marinus L., is eating now in Puerto Rico, J. Agr. Univ. P. R. 21 (1) 79-84, (ref. 3.) 1937.

4. Pérez, Mario E., The food of Rana catesbeiana Shaw in Puerto Rico, J. Agr. Univ. P. R. 35 (4) 136-142 (ref. 11.) 1951.

5. Morgan, A. C., A new genus, a new subgenus and seven new species of Thysanoptera from Puerto Rico, Fl. Entomologist 9 (1) 1-9, 1925.

6. Petrunkevitch, Alex., The spiders of Porto Rico, Trans. Conn. Academy of Arts and Sciences 30 (1) 1-158, fig. 150, and (2) 159-355, fig. 240; 31 (3) 1-191, fig. 168, 1929 and 1930.

7. Pemberton, C. E., Some Food Habits of the Mongoose, Hawaiian Planters' Rec. 37 (1) 12-13, fig. 1, December 1933. 


\section{Erratum}

Jr. of Agric. Univ. of P. R. 36: (3) 1952, page 278, 2nd paragraph, word on line 9 should be "structure" instead of "texture." 